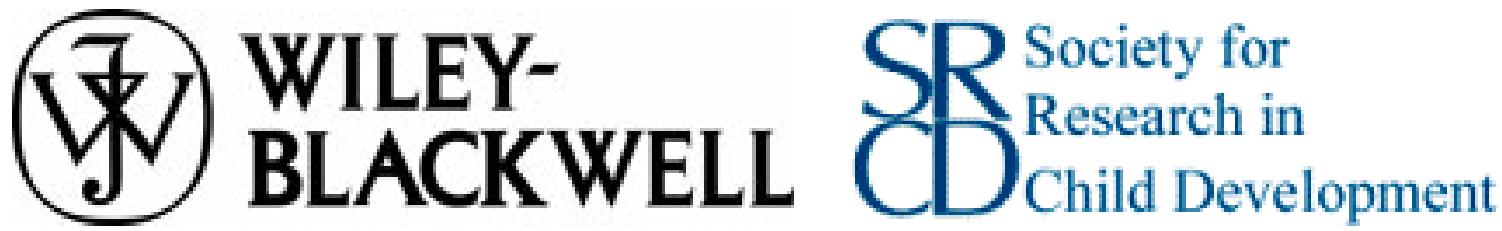

A Reliability Study of Speech Sounds Observed in the Crying of Newborn Infants Author(s): Orvis C. Irwin and Han Piao Chen

Source: Child Development, Vol. 12, No. 4 (Dec., 1941), pp. 351-368

Published by: Blackwell Publishing on behalf of the Society for Research in Child Development

Stable URL: http://www.jstor.org/stable/1125603

Accessed: $17 / 01 / 201111: 13$

Your use of the JSTOR archive indicates your acceptance of JSTOR's Terms and Conditions of Use, available at http://www.jstor.org/page/info/about/policies/terms.jsp. JSTOR's Terms and Conditions of Use provides, in part, that unless you have obtained prior permission, you may not download an entire issue of a journal or multiple copies of articles, and you may use content in the JSTOR archive only for your personal, non-commercial use.

Please contact the publisher regarding any further use of this work. Publisher contact information may be obtained at http://www.jstor.org/action/showPublisher?publisherCode=black.

Each copy of any part of a JSTOR transmission must contain the same copyright notice that appears on the screen or printed page of such transmission.

JSTOR is a not-for-profit service that helps scholars, researchers, and students discover, use, and build upon a wide range of content in a trusted digital archive. We use information technology and tools to increase productivity and facilitate new forms of scholarship. For more information about JSTOR, please contact support@jstor.org.

Blackwell Publishing and Society for Research in Child Development are collaborating with JSTOR to digitize, preserve and extend access to Child Development. 


\section{A RELIABILITY STUDY OF SPEECH SOUNDS OBSERVED \\ IN THE CRYING OF NEWBORN INFANTS 1}

\section{ORVIS C. IRWIN AND HAN PIAO CHEN}

\section{INTRODUCTION}

In any research program the primary concerm is to saleguard the data. The term "safeguarding the data" here is taken to mean that they are: 1) reliable and 2) valid. This study is concerned with the first of these two problems. Rellability usually is treated under two headings: 1) the problem of observer rellability and 2) the rellability of the data. The purpose of this study is to investigate both of these problems in regard to early speech sounds, especially when they occur during the crying of newborm infants.

The general status of the problem of the reliablifty of infant speech sound data has been reviewed by Irwin (1). A study of Irwin and Curry (2) reported on the rellability of recording vowel sounds of newborn infants, and Irwin and Krehblel (3) in an unpublished study reported both observer and data rellablilty of transcriptions of vowel and consonants of four-, 11ve-, and six-month infants. In all the studies now being conducted the International Phonetic Alphabet is used to transcribe sounds.

In the present study two experiments were conducted, one of which Involved a small sample or crying sounds from each of 40 infants; ${ }^{2}$ the other, a fairly large sample from each of 5 infants. The unit of observation was the respiration (2). In the first experiment the sample consisted of the sounds carried on each of 30 exhllations giving a total of 1200 breaths for the group. The total number of individual vowel elements on these 1200 respirations amounted to 1520. In the second experiment the sample consisted of the sounds carried on 180 breaths for each baby giving a total of 900 breaths for the group. The total number of separate vowel sounds amounted to 1080. In addition a further analysis of the Irwin-Curry data has been made. Th1s sample consists of the sounds carried on 25 respirations of each of 40 infants or a total of 1000 breaths which ylelded a total of 1285 vowel sounds. The date under analyses then consist of three samples with a grand total of 3885 vowel sounds.

\section{WHINING AND CRYING}

In the study by Irwin and Curry a discrimination was made between crying and non-crying sounds. However since non-crying sounds are of rare occurrence in newborms, no report can be made at present concerning them. In the two experiments of the present study a further discrimination was made between crying and whining sounds. A report on the latter w1ll be deferred unt1l later but 1t does involve the necessity or

\footnotetext{
1 From the Iowa Chtld Welfare Research Station, Untversity of Iowa, Iowa Ctty, Iowa.

2 Ten of these subjects were negro infants. A systemat tc study of ractal differences in speech sound equitoment of newborns will be reported later.
}

351

CHILD DEVELOPMENT, Vol. 12, No. 4 (December, 1941) 
establishing observer rellablilty for discriminating these two categorles. Accordingly this problem also was undertaken.

Two observers simultaneously but independently recorded 60 breaths on each of 5 infants. Speech sounds as such were disregarded and the record on each of the 300 breaths consisted e1ther of the term "whining" or "crying." In determining the difference between whining and crying in newborns, the observers used the following set of criteria:

1. Regularity of respiration

2. Shape of mouth opening

3. Tongue position

4. Face and I1d contraction

5. Loudness of sound

On the basis of these criteria the condition of crying is defined as regularity of breathing, the mouth is opened wide, usually in a rectangular shape, the tip of the tongue is elevated, the muscles of the face are strongly contracted and the eyelids tightly closed, and the sound is uttered with force or loudness. Whining is defined as occurring during irregular breathing, the mouth is partially opened, the tongue tip is not elevated, the muscles of the face are only slightly contracted, the lids are open or if closed are not tightly contracted, and the sounds are feeble.

The following tabulation presents the data on the 5 cases. That crying and whining may be rellably discriminated is evident. The per cent of agreement between the two observers ranged from 95 to 100, the average being 97 per cent.

$\begin{array}{cc}\text { Subject } & \begin{array}{r}\text { Per Cent } \\ \text { Agreement }\end{array} \\ 1 & 97 \\ 2 & 95 \\ 3 & 100 \\ 4 & 97 \\ 5 & 95 \\ \text { Average } & 97\end{array}$

\section{RELIABILITY IN TERMS OF FREQUENCY AND} OF THE OBSERVED BEHAVIOR UNIT

The problem of observer rellability of speech sound data in newborms may be approached in two ways: 1) agreement in terms of the total number of speech elements considered as separate events, and 2) agreement in terms of the patterm of elements occurring on the respiration or breath. The former will be called frequency agreement, the latter breath agreement. In the case of the former the erequencies of each vowel element are calculated as a per cent of the total number of elements uttered regardless of patterming. Th1s is done for each observer and the corresponding values for both are compared on a per cent basis.

A more rigorous analysis is concermed with the agreement between two observers' transcriptions when the pattern of sounds occurring on the breath is considered. The problem will be clarifled by indicating several possible cases. The first case is presented when one observer hears the sound $\Lambda$ on a breath whereas the other records the sound $\underline{\varepsilon}$. 
Th1s const1tutes disagreement. In the second case one observer might hear the sounds $\underline{\xi}$, and $I$ on a given breath and the second observer also might hear these sounds. Obviously this const1tutes 100 per cent agre日ment. However there is a third possibility in which there 18 agreement on some of the sounds occurring on a breath and disagreement on others. one observer may record the sounds $\varepsilon, \Lambda$ on a given breath, whereas the other hears $\mathbb{L}, \underline{\Lambda}$. In this case, of a total of four sounds, two are disagreements and two are agreements. Accordingly the index is 50 per cent. Th1s has been termed the mixed category.

All sounds, therefore, have been analyzed 11rst into three categorles: agreements, disagreements, and mixtures. Then the sounds classifled in the mixed group in turn have been calculated in per cents of agreement and disagreement, and their values have been added to the original categories of agreement and disagreement. The three categories thus have been reduced to two and in this manner an index has been derived to indicate breath agreement.

\section{EXPERIMENT 1}

Table 1 gives the per cent of agreement for two observers for both breath and erequency in experiment 1 on each of 40 bables. The average agreement in terms of the breath unit is 91 per cent. For the frequencies it is 93 per cent.

The following tabulation indicates how the two sets of agreements are distributed. It will be seen that in the case of the breath unit there was agreement above 97 per cent on 12 infants, above 93 per cent on 18 infants, above 85 per cent on 33 of the 40 subjects. In terms of total erequency of sound elements there was agreement above 97 per cent on 17 infants, above 93 per cent with 27 infants, and above 85 per cent with 36 of the 40 subjects. In the case of breath agreement 6 indices

Cumu-

\begin{tabular}{ccc}
$\begin{array}{c}\text { Agreement, } \\
\text { Per Cent }\end{array}$ & $\begin{array}{c}\text { Fre- } \\
\text { quency }\end{array}$ & $\begin{array}{c}\text { lat1ve } \\
\text { Fre- } \\
\text { quency }\end{array}$ \\
\multicolumn{4}{c}{ Breath Un1t } & \\
97 to 100 & 12 & 12 \\
93 to 96 & 6 & 18 \\
89 to 92 & 9 & 27 \\
85 to 88 & 6 & 33 \\
81 to 84 & 1 & 34 \\
77 to 80 & 2 & 36 \\
73 to 76 & 4 & 40 \\
Total & 40 &
\end{tabular}

Total Frequency

$\begin{array}{lrr}97 \text { to } 100 & 17 & 17 \\ 93 \text { to } 96 & 10 & 27 \\ 89 \text { to } 92 & 5 & 32 \\ 85 \text { to } 88 & 4 & 36 \\ 81 \text { to } 84 & 2 & 38 \\ 77 \text { to } 80 & 1 & 39 \\ 73 \text { to } 76 & 1 & 40 \\ \text { Total } & 40 & \end{array}$


IRWIN: RELIABILITY IN OBSERVING SOUNDS

\begin{tabular}{|c|c|c|}
\hline \multicolumn{3}{|c|}{$\begin{array}{c}\text { TABLE I } \\
\text { Observer Reliability of Crying } \\
\text { Sounds of Forty Babies }\end{array}$} \\
\hline $\begin{array}{l}\text { Infant } \\
\text { Number }\end{array}$ & $\begin{array}{l}\text { Frequency } \\
\text { Agreement, } \\
\text { Per Cent }\end{array}$ & $\begin{array}{l}\text { Breath } \\
\text { Agreement, } \\
\text { Per Cent }\end{array}$ \\
\hline $\begin{array}{r}1 \\
2 \\
3 \\
4 \\
5 \\
6 \\
7 \\
8 \\
9 \\
10 \\
11 \\
12 \\
13 \\
14 \\
15 \\
16 \\
17 \\
18 \\
19 \\
20 \\
21 \\
22 \\
23 \\
24 \\
25 \\
26 \\
27 \\
28 \\
29 \\
30 \\
31 \\
32 \\
33 \\
34 \\
35 \\
36 \\
37 \\
38 \\
39 \\
40 \\
\text { Average }\end{array}$ & $\begin{array}{r}74 \\
98 \\
87 \\
100 \\
94 \\
94 \\
80 \\
86 \\
89 \\
82 \\
98 \\
100 \\
100 \\
82 \\
93 \\
92 \\
100 \\
100 \\
86 \\
94 \\
97 \\
95 \\
97 \\
97 \\
94 \\
95 \\
100 \\
97 \\
100 \\
87 \\
95 \\
92 \\
90 \\
89 \\
93 \\
100 \\
97 \\
100 \\
98 \\
95 \\
93\end{array}$ & $\begin{array}{r}76 \\
74 \\
77 \\
100 \\
74 \\
86 \\
88 \\
87 \\
79 \\
89 \\
96 \\
93 \\
100 \\
76 \\
89 \\
82 \\
100 \\
98 \\
85 \\
98 \\
99 \\
91 \\
99 \\
90 \\
96 \\
88 \\
96 \\
97 \\
100 \\
90 \\
89 \\
88 \\
91 \\
92 \\
91 \\
94 \\
94 \\
100 \\
97 \\
97 \\
91\end{array}$ \\
\hline
\end{tabular}

fall between 70 and 80 per cent whereas in the case of frequency agreement 2 indices fall between these limits.

Thus with elther method a quite satisfactory observer rellability is established.

A graphic method of presenting the dispersion of speech elements involving the principle of the profile was described in a previous report (4). Figure I includes six profiles comparing the dispersion vowel sounds of newborms as recorded by three palrs of observers. The two upper proffles give the percent of erequency of observer I and observer 
OBSERVED RELIABILITY ON PER CENT OF FREQUENCY OF VOWEL SOUNOS OF NEWBORNS

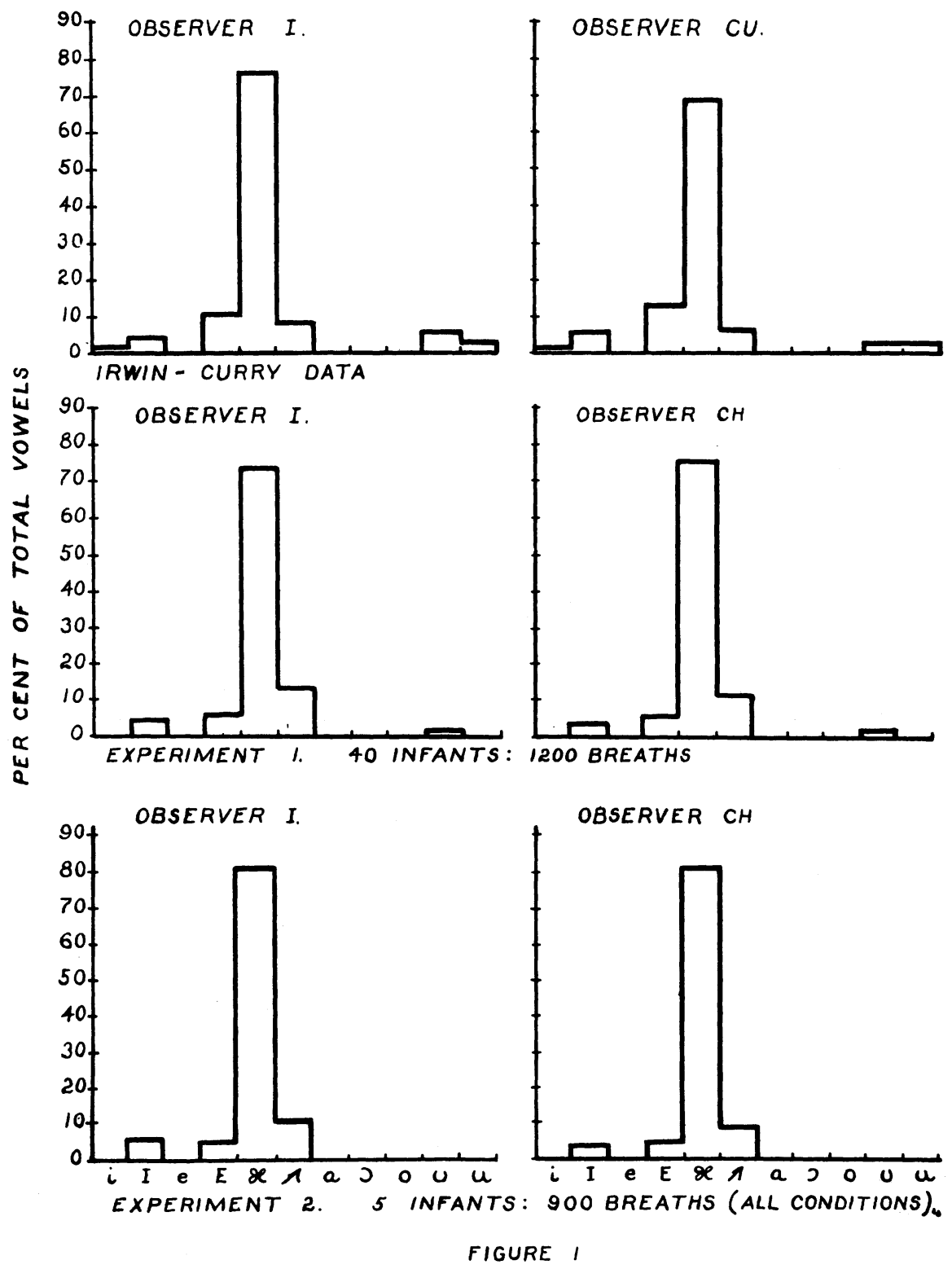


Cu. There is striking similarity between the patterns of these two observers. The two middle profiles were constructed from the data of experiment 1 , and likewise show similarity of pattern. The two lower profiles are based on the data in experiment 2. Here again there is great similarity. The comparisons between the records of pairs of profiles quite adequately indicate the degree of observer rellability which may be achleved with this type of data.

It is of interest to note the trends which occur during the course of collecting the data. They are indicated in Figure 2. The curves represent the average agreements of elght successive groups of 5 bables. Thus the observer rellability on the first 5 bables is about 80 per cent. on the last 5 it is about 95 per cent. One curve represents the IrwinCurry data, the other the Irwin-chen data. While there are some differences between the two curves, they start together, they end together, and they indicate that an untrained observer will raise his reliability to over 90 per cent after working with about 18 infants. The figure thus is of practical value in conducting research on sounds for it tells approximately how many subjects should be used to train new observers.

There is a special problem involved in the derivation of the reliability index by the two methods. As was noted the per cent of breath agreement is 91 , the per cent of frequency agreement is 93. Superf1clally 1t would seem that these two values are sufficiently close so that one method could be substituted for the other. That this is not the case will become apparent from the following reasoning.

When the two sets of values are correlated the coefficlent of correlation $18.75 \pm .03$. Ordinarily this might be considered a high correlation. However the coefficlent of allenation, which measures the absence of relationship, amounts to .66 . This value is too high to permit a substitution of one of these methods for the other. It may be inferred then that the two methods may not rank the infants alike. To test this inference, the index of forecasting efficiency may be applied. In order that one might predict scores derived by one of these methods from scores derived by the other method, a very high correlation is necessary. A correlation of .995 is required to reduce errors in prediction to 90 per cent. A correlation of 75 gives a percentage reduction over chance in errors of prediction of only 32.9. The two methods, therefore, do not rank the infants in the same order. This is another way of saying that the scores from the method of erequency agreement cannot be substituted for those derived by the method of breath agreement. A cautious interpretation of the correlation value of .75 therefore requires that both methods be used in computing observer rellabilities on speech date at the newborn level.

The reason that the two methods do not rank the individuals alike may 110 in the lact that they represent two different problems. The method of breath agreement answers the question - what in terms of the observation unit (the single respiration) actually used is the observer agreement. The erequency method answers the question - what agreement may be achieved with a large amount of data collected over an extended period without regard for the observation unit. Quite evidently these are two different problems.

The Irwin-Curry data may be similarly interpreted. The correlation 
IRWIN: RELIABILITY IN OBSERVING SOUNDS

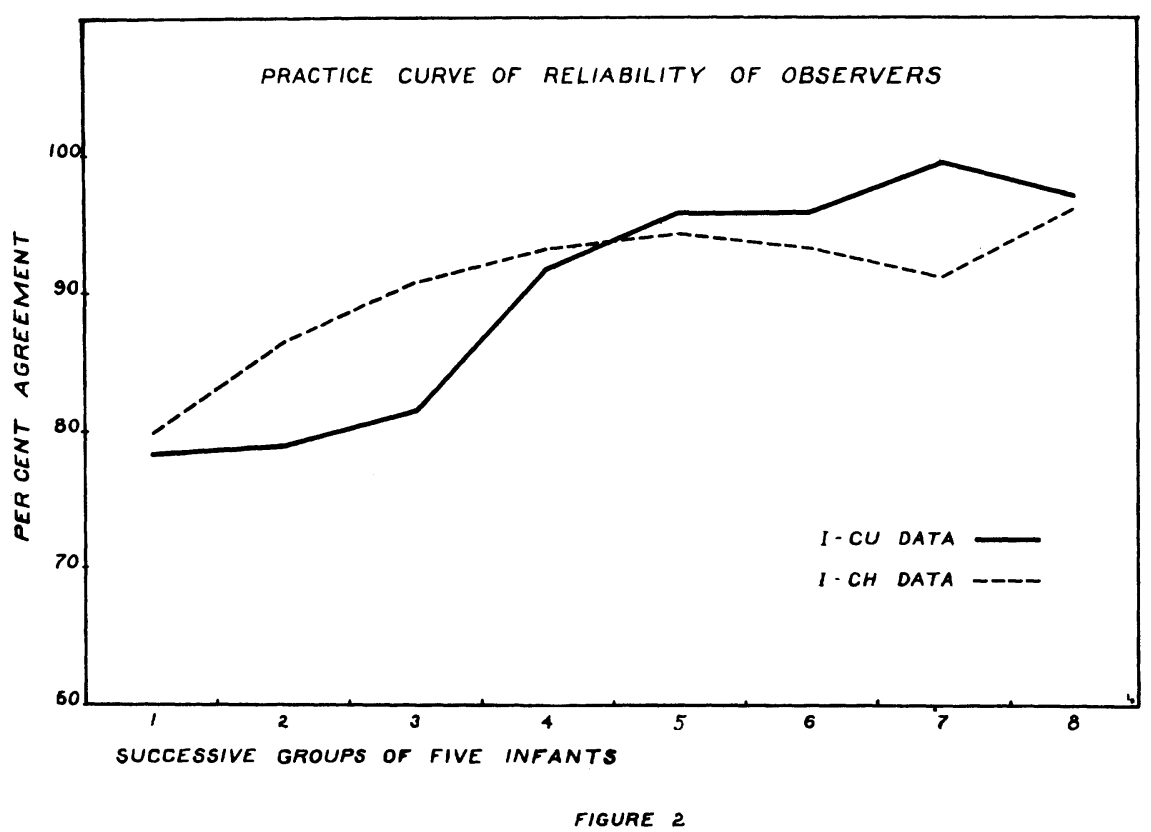

value between the breath and Irequency ratings of this study amounts to .94. Th1s is much higher than the previous value of .75. Nevertheless the index of forecasting efficiency for this correlation value is 65.8 , not a very satisfactory value. The coefficient of allenation is . 342 indicating the amount of absence of relationship. Here, too, evidence is forthcoming that the frequency method of establishing observer rellability cannot be substituted for breath rellability. The conclusion that both methods should be employed seems to be re-enforced by this study.

There is a fundamental criticism which may be leveled against this procedure of establishing observer rellability. It is that the untrained observer learns not only the correct habits of transcription from the trained observer but also he learns the errors of the trained observer. Th1s means that the rellablilty index of 93 per cent is as high as it is because both correct and incorrect habits of transcribing are compared.

The situation has been safeguarded by requiring the trained observer (I) to take all courses in phonetics, both undergraduate and graduate, offered in the university. H1s orlginal training was conducted by a trained phonetician. In addition he worked with several other experienced phonet1cians so that his hablts were not determined by a single individual. Moreover, in order to maintain a high degree of accuracy in the use of phonetic symbols, this observer has made it a pollcy to repeat attendance on these courses and engages in regular practice to maintain skill. 


\section{EXPERIMENT 2}

In the second experiment 5 bables were used w1th a total of 180 observations on each. Thus it affords a comparison of a large number of observations on a small sample with the result of the first experiment in wh1ch 30 observations were made on each of 40 bables. In addition, this experiment was designed to answer an important question concerning the collection of speech data. In an earlier study (2) it was pointed out that the use of the short time sample falled to yleld a satisfactory rellability. Accordingly a short behavior unit, the single breath carrying from one to flve sounds, which falls well within the ordinary attention span of the observer, was used instead of a time sample. The individual respirations themselves, however, during violent crying occaslonally may occur so rapldiy that the observer cannot transcribe the sounds occurring on consecutive breaths. This is a fundamental criticism of the method of the short behavior sample. Mccarthy (5) has made this criticism against the general method of phonet1c transcription. That it can be circumvented, however, will be apparent from what follows.

A record of 60 breaths was taken simultaneously and independentily under three different conditions by the two observers. Transcriptions were made of 60 consecutive breaths, of 60 alternate breaths, and of 60 fourth breaths. If a comparison of these three types of transcriptions should reveal striking differences then the criticism is a valid one. If, however, the per cents of agreement are well above 90 then every second or fourth, etc., breath, instead of consecutive breaths, may be transcribed with satisfactory results. That the latter is the case in terms of breath agreement is evident from the following tabulation which

\begin{tabular}{|c|c|c|}
\hline \multirow[t]{2}{*}{$\begin{array}{l}\text { Infant } \\
\text { Number }\end{array}$} & Condition & $\begin{array}{c}\text { Breath } \\
\text { Agreement, } \\
\text { Per Cent }\end{array}$ \\
\hline & Consecutive & 85 \\
\hline \multirow[t]{3}{*}{1} & Alternative & 84 \\
\hline & Every 4th & 84 \\
\hline & Consecutive & 97 \\
\hline \multirow[t]{3}{*}{2} & Alternative & 98 \\
\hline & Every 4th & 97 \\
\hline & Consecutive & 96 \\
\hline \multirow[t]{3}{*}{3} & Alternative & 96 \\
\hline & Every 4 th & 97 \\
\hline & Consecutive & 97 \\
\hline \multirow[t]{3}{*}{4} & Alternative & 98 \\
\hline & Every 4th & 98 \\
\hline & Consecutive & 97 \\
\hline \multirow[t]{2}{*}{5} & Altermative & 98 \\
\hline & Every 4th & 96 \\
\hline \multirow[t]{2}{*}{ Average } & & 95 \\
\hline & Consecutive & 94 \\
\hline \multirow{2}{*}{ Average } & Alternat1ve & 95 \\
\hline & Every 4 th & 94 \\
\hline
\end{tabular}


presents observer rellability of crying sounds of the 5 bables under three conditions. All of the per cent values, it is evident, $11 \theta$ in the nineties except three on the 1irst infant. It will be noted that the average agreements for the three conditions are practically the same.

In terms of frequency agreement the result is the same. This can be seen in the following tabulation.

$\begin{array}{clc}\begin{array}{c}\text { Infant } \\ \text { Number }\end{array} & \text { Condition } & \begin{array}{r}\text { Frequency } \\ \text { Agreement, } \\ \text { Per Cent }\end{array} \\ 1 & \text { Consecutive } & 87 \\ & \text { Alternative } & 99 \\ & \text { Every 4th } & 86 \\ 2 & \text { Consecut1ve } & 100 \\ & \text { Alternative } & 97 \\ & \text { Every 4th } & 97 \\ & \text { Consecut1ve } & 96 \\ 3 & \text { Alternative } & 99 \\ & \text { Every 4th } & 99 \\ & \text { Consecut1ve } & 99 \\ 4 & \text { Alternative } & 95 \\ & \text { Every 4th } & 100 \\ & \text { Consecutive } & 97 \\ 5 & \text { Alternative } & 97 \\ & \text { Every 4th } & 96 \\ \text { Average } & & 96\end{array}$

The average observer agreements under different conditions are:

$\begin{array}{ll}\text { Consecutive } & 96 \\ \text { Alternative } & 97 \\ \text { Every 4th } & 96\end{array}$

Moreover, so far as observer rellablilty is concerned, these tabulations reveal that a large sample of sounds from a small sample of subjects gives as satisfactory results as a small sample of sounds from a large sample of infants.

\section{OBSERVER RELIABILITY OF THE FREQUUNCY OF SEPARATE VOWELS}

Another problem remains to be considered. What is the rellability of the observers on each of the vowel elements? The next tabulation considers this problem for the experiment which involved forty subjects. The second and third colume give the frequency of occurrence of each of five vowel sounds as recorded by the observers. The fourth column shows the per cent of agreement. It will be seen that there is very high agreement, 99 per cent, on the sound $\dot{x}$, wh1ch is the most erequent sound. The lowest per cent of agreement occurs in the sound $I$. Thus 
the tabulation shows that for most of the sounds uttered by newborm infants there is good agreement. The average per cent of agreement is 85. When the erequencies themselves are transformed into per cents of the total number of sounds heard, the result is found in the last three columns.

\begin{tabular}{|c|c|c|c|c|c|c|}
\hline \multirow{3}{*}{ Vowel } & \multicolumn{3}{|c|}{ Frequency } & \multicolumn{3}{|c|}{ Per Cent } \\
\hline & \multicolumn{2}{|c|}{ Observer } & \multirow{2}{*}{$\begin{array}{l}\text { Agree- } \\
\text { ment, } \\
\text { Per } \\
\text { Cent }\end{array}$} & \multicolumn{2}{|c|}{ Observer } & $\begin{array}{l}\text { Agree- } \\
\text { ment, }\end{array}$ \\
\hline & I & $\mathrm{Ch}$ & & I & $\mathrm{Ch}$ & $\begin{array}{r}\text { Per } \\
\text { Cent }\end{array}$ \\
\hline I & 79 & 47 & 60 & 5.1 & 3.2 & 63 \\
\hline$\varepsilon$ & 85 & 82 & 96 & 5.4 & 5.5 & 98 \\
\hline $\mathscr{x}$ & 1,165 & 1,153 & 99 & 74.7 & 78.0 & 96 \\
\hline$\Lambda$ & 219 & 187 & 85 & 14.0 & 12.6 & 90 \\
\hline u & 12 & 10 & 83 & .8 & .7 & 88 \\
\hline Total & 1,560 & 1,479 & & 100.0 & 100.0 & \\
\hline
\end{tabular}

The following tabulation presents simflar analyses of rellabllity on separate vowels in the second experiment which involved five subjects. only four sounds were heard during this experiment. The per cent of agreement varies from 82 on the vowel I to 99 on the sound $\not$. The average per cent agreement here is 89.

\begin{tabular}{|c|c|c|c|c|c|c|}
\hline \multirow{3}{*}{ Vowel } & \multicolumn{3}{|c|}{ Frequency } & \multicolumn{3}{|c|}{ Per Cent } \\
\hline & \multicolumn{2}{|c|}{ Observer } & \multirow{2}{*}{$\begin{array}{l}\text { Agree- } \\
\text { ment, } \\
\text { Per } \\
\text { Cent }\end{array}$} & \multicolumn{2}{|c|}{ Observer } & $\begin{array}{l}\text { Agree- } \\
\text { ment, }\end{array}$ \\
\hline & I & $\mathrm{Ch}$ & & I & $\mathrm{Ch}$ & $\begin{array}{l}\text { Per } \\
\text { Cent }\end{array}$ \\
\hline I & 50 & 41 & 82 & 4.6 & 3.9 & 85 \\
\hline$\varepsilon$ & 46 & 52 & 88 & 4.2 & 4.9 & 86 \\
\hline$x$ & 873 & 865 & 99 & 79.9 & 81.2 & 98 \\
\hline$\Lambda$ & 124 & 107 & 86 & 11.3 & 10.0 & 89 \\
\hline Total & 1,093 & 1,065 & & 100.0 & 100.0 & \\
\hline
\end{tabular}

\section{DATA RELIABILITY}

The problem of the reliability of the data will be handled in three ways: 1) by comparing sounds occurring on the consecutive, alternative and fourth breaths; 2) by comparing odd-even items; and 3) by comparing the results of three experiments.

Comparison of Consecutive, Alternat1ve, and Fourth Respirations

In Figure 1 the lower pair of profiles was based upon data collected in experiment 2 under three conditions. These two profiles indicate the results of the three conditions when they are totalled. In Figure 3, however, a further analysis of these data is presented in profiles representing the dispersion of vowel sounds under each of the three conditions. The three profiles arranged vertically at the left show the patterms of the three samples taken consecutively, alternately and on every fourth breath by one of the observers. It 18 clear that with quite minor variations these three patterns are al1ke. Likewise the 
IRWIN: RELIABILITY IN OBSERVING SOUNDS

SAMPLE RELIABILITY OF PER CENT OF FREQUENCY OF VOWEL SOUNDS OF NEWBORNS UNDER THREE CONDITIONS

OBSERVER I
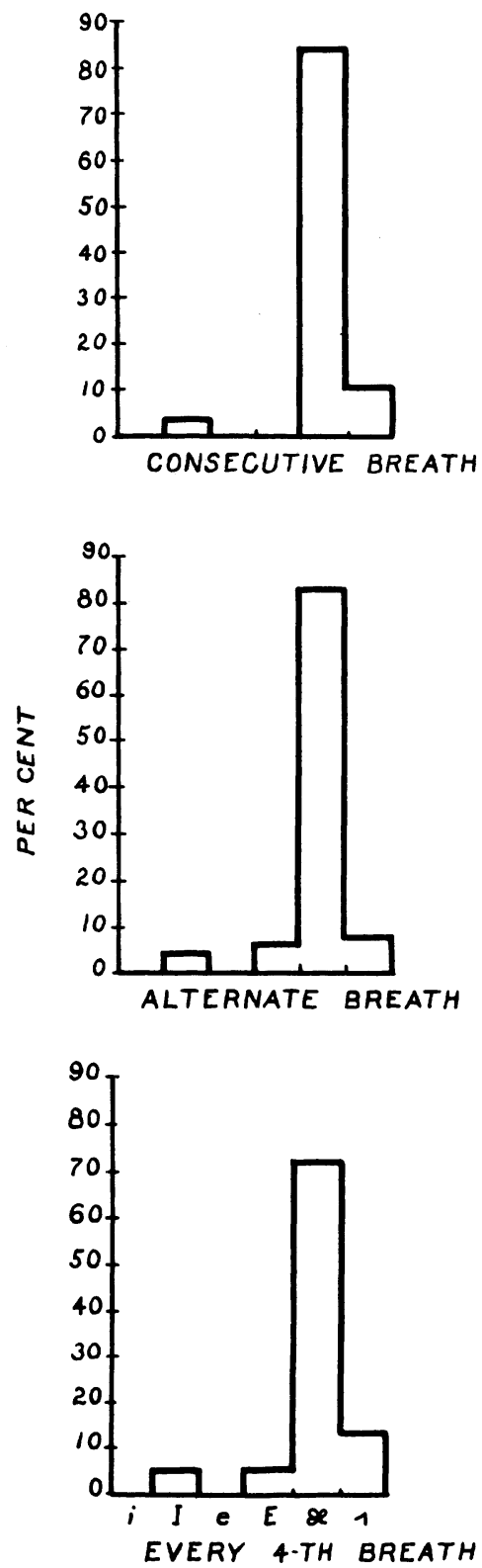

OBSERVER $\mathrm{CH}$
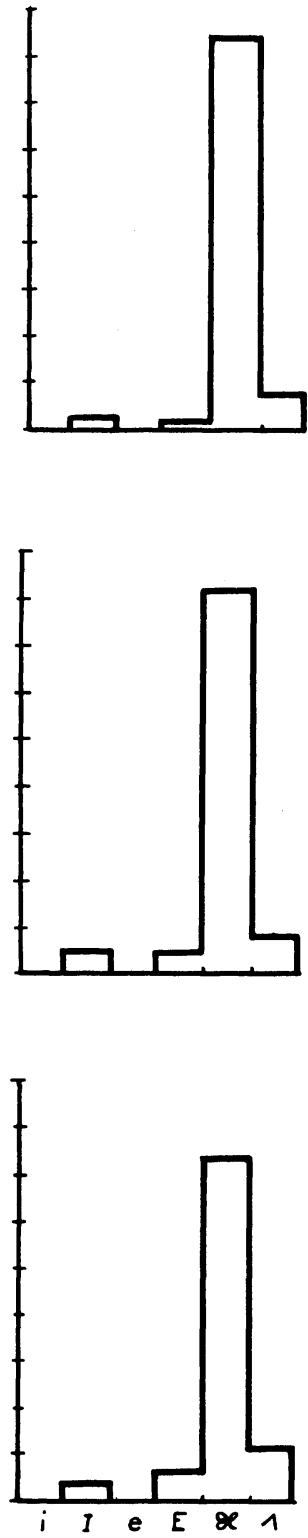

FIGURE 3 
three profiles at the right of the figure exhlbit a high degree of similarity.

It is readily noted that of the four sounds transcribed in this experiment the vowel ge clearly dominates. Consistently the vowel $\triangle$ maintains second place, while $I$ and $\underline{\varepsilon}$ show variation. These vertical comparisons thus demonstrate in a graphical manner the rellability of the data within this sample.

Incidentally a horizontal comparison of the palrs of profiles reveals a high observer reliability within experiment 2 .

\section{Comparison of Odd-Even Items}

A second demonstration of the reliability of the data is afforded by a comparison of odd-even 1tems. An analysis of these 1 tems will be made of the data of both experiments 1 and 2 .

The next tabulation presents the odd-even 1tems of different vowels made by the 40 infants in experiment 1. The tabulation is read: for observer I the sound $\mathscr{H}$ occurred 580 times on the odd transcriptions and 585 times on the even, the per cent of agreement being 99. Other sounds are read accordingly.

When the corresponding values for the two observers are averaged and then turned into percentages the results may be seen in the profiles of Figure 4. It is evident from the similarity of these profiles that the rellability of the data in this experiment in terms of odd-oven 1tems is quite adequate. In both profiles the \& sound not only dominates the dispersions but their values differ by less than $I$ per cent. The order

SAMPLE RELIABILITY OF PERCENT OF FREQUENCY OF VOWELS ( 40 INFANTS) EXPERIMENT I.
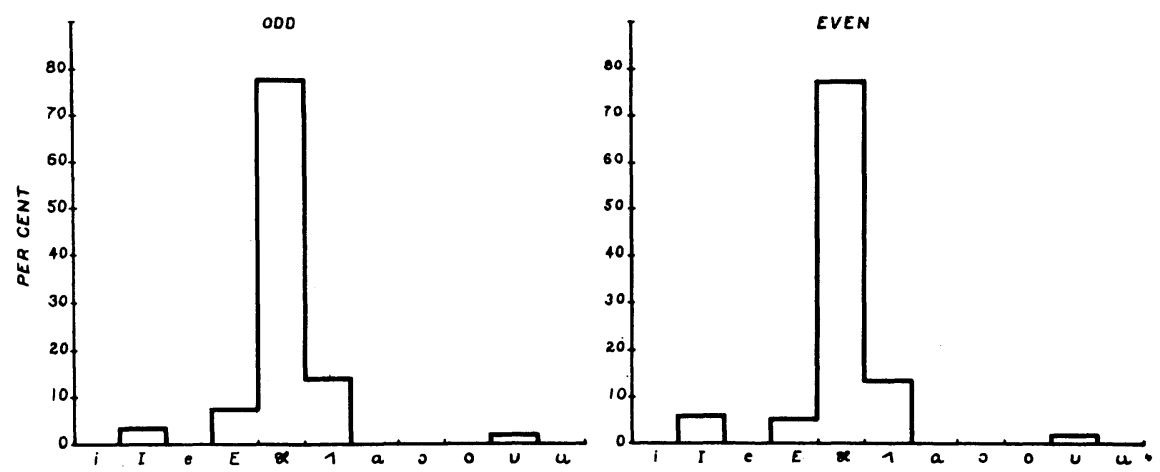

FIGURE 4

of dispersion for the odd and the even values is the same: $\mathscr{H}, \Delta, \underline{\varepsilon}, \underline{I}$, and $\underline{u}$. The corresponding values in each case differ by less than 1 per cent. Separate profiles of the odd-even 1tems of each of the observers have not been included since those of Figure 3, w1th very slight modifications, could be substituted for them.

In experiment 2 , in which five infants were used, the problem of 
IFWIN: RELIABILITY IN OBSERVING SOUNDS

\begin{tabular}{|c|c|c|c|}
\hline \multirow[t]{2}{*}{ Vowel } & \multicolumn{2}{|c|}{ Frequency } & \multirow{2}{*}{$\begin{array}{c}\text { Agreement, } \\
\text { Per Cent }\end{array}$} \\
\hline & Odd & Even & \\
\hline & \multicolumn{2}{|c|}{ Observer I } & \\
\hline I & 32 & 47 & 67 \\
\hline$\varepsilon$ & 44 & 41 & 93 \\
\hline$x$ & 580 & 585 & 99 \\
\hline$\wedge$ & 109 & 110 & 99 \\
\hline$u$ & 6 & 6 & 100 \\
\hline \multirow[t]{2}{*}{ Total } & 771 & 789 & \\
\hline & \multicolumn{2}{|c|}{ Observer Ch } & \\
\hline$I$ & 19 & 28 & 68 \\
\hline$\varepsilon$ & 45 & 37 & 82 \\
\hline H & 576 & 577 & 100 \\
\hline$\Lambda$ & 92 & 95 & 97 \\
\hline$u$ & 6 & 4 & 67 \\
\hline \multirow[t]{2}{*}{ Total } & 738 & 741 & \\
\hline & \multicolumn{2}{|c|}{ Average } & \\
\hline I & 25.5 & 37.5 & 68 \\
\hline$\varepsilon$ & 44.5 & 39.0 & 88 \\
\hline H & 587.0 & 581.0 & 99 \\
\hline$\wedge$ & 100.5 & 102.5 & 98 \\
\hline$u$ & 6.0 & 5.0 & 83 \\
\hline Total & 754.5 & 765.0 & \\
\hline \multicolumn{3}{|c|}{ Average } & 87 \\
\hline
\end{tabular}

data rellability will be dealt with in two ways: 1) by comparing the odd-even agreement of speech 1 tems in each of the categories of consecutive, alternative, and lourth transcriptions; and 2) by comparing these three categories with each other.

Table 2 presents the odd-even erequencles of the different vowels made by five bables under the three different conditions. The table may be read thus: for observer I's data, the vowel sound He occurred 150 times in his odd consecutive transcriptions, and 151 times in the even ones. The per cent of agreement 1s 100. This vowel occurred 144 times on his odd altermative transcriptions and 144 on his even ones. It occurred 139 times on his odd fourth transcription and 145 times on his even, etc. The second part of the table gives the corresponding results for observer $\mathrm{Ch}$, and the third part gives the average values for the two observers.

When the averaged results are transformed into per cent values and plotted as profiles the result is seen in Figure 5. The profiles reveal that under the condition of consecutive transcription the order for both the odd and the even values is: $\mathcal{H}, \underline{\underline{\mu}}, \underline{I}, \underline{\varepsilon}$. For both the altermative and fourth transcriptions the odd and even order is 11rst $\mathscr{R}$ and then $\Lambda$, but there is some variation in regard to the rank of $I$ and $\underline{\varepsilon}$. However the differences between the odd and even values are negligible. The largest difference amounts to 5 per cent between \& recorded on the even transcriptions and $\&$ on the odd transcriptions. This difference 18 
IRWIN: RELIABILITY IN OBSERVING SOUNDS

TABLE 2

FREQUENCIES OF THE DIFFERENT VOWELS MADE BY FIVE BABIES UNDER THE THREE DIFFERENT CONDITIONS

\begin{tabular}{|c|c|c|c|c|c|c|c|c|c|}
\hline \multirow{3}{*}{ Vowel } & \multicolumn{3}{|c|}{ Consecutive } & \multicolumn{3}{|c|}{ Alternative } & \multicolumn{3}{|c|}{ Fourth } \\
\hline & \multicolumn{2}{|c|}{ Frequency } & \multirow{2}{*}{$\begin{array}{l}\text { Agree- } \\
\text { ment, } \\
\text { Per Cent }\end{array}$} & \multicolumn{2}{|c|}{ Frequency } & \multirow{2}{*}{$\begin{array}{c}\text { Agree- } \\
\text { ment, } \\
\text { Per Cent }\end{array}$} & \multicolumn{2}{|c|}{ Frequency } & \multirow{2}{*}{$\begin{array}{c}\text { Agree- } \\
\text { ment, } \\
\text { Per.cent }\end{array}$} \\
\hline & Odd & Even & & Odd & Even & & Odd & Even & \\
\hline \multicolumn{10}{|c|}{ Observer I } \\
\hline $\begin{array}{c}I \\
\varepsilon \\
\mathscr{H} \\
{ }^{n} \hat{\wedge} \\
\text { Total }\end{array}$ & $\begin{array}{c}7 \\
0 \\
150 \\
24 \\
181\end{array}$ & $\begin{array}{r}9 \\
0 \\
151 \\
17 \\
177\end{array}$ & $\begin{array}{r}78 \\
100 \\
71\end{array}$ & $\begin{array}{r}7 \\
10 \\
144 \\
16 \\
177\end{array}$ & $\begin{array}{r}5 \\
10 \\
144 \\
12 \\
171\end{array}$ & $\begin{array}{r}71 \\
100 \\
100 \\
75\end{array}$ & $\begin{array}{r}11 \\
18 \\
139 \\
29 \\
197\end{array}$ & $\begin{array}{r}11 \\
8 \\
145 \\
26 \\
190\end{array}$ & $\begin{array}{r}100 \\
44 \\
96 \\
90\end{array}$ \\
\hline \multicolumn{10}{|c|}{ Observer $\mathrm{Ch}$} \\
\hline $\begin{array}{c}I \\
E \\
\mathscr{X} \\
\wedge \\
\text { Total }\end{array}$ & $\begin{array}{r}1 \\
3 \\
147 \\
12 \\
163\end{array}$ & $\begin{array}{r}9 \\
5 \\
147 \\
19 \\
180\end{array}$ & $\begin{array}{r}11 \\
60 \\
100 \\
63\end{array}$ & $\begin{array}{r}5 \\
10 \\
142 \\
20 \\
177\end{array}$ & $\begin{array}{r}10 \\
9 \\
145 \\
11 \\
175\end{array}$ & $\begin{array}{l}50 \\
90 \\
98 \\
55\end{array}$ & $\begin{array}{r}8 \\
16 \\
141 \\
24 \\
189\end{array}$ & $\begin{array}{r}8 \\
9 \\
143 \\
21 \\
181\end{array}$ & $\begin{array}{r}100 \\
56 \\
99 \\
88\end{array}$ \\
\hline \multicolumn{10}{|c|}{ Average } \\
\hline $\begin{array}{c}I \\
\varepsilon \\
\not H \\
\wedge \\
\text { Total }\end{array}$ & $\begin{array}{r}4 \\
1.5 \\
148.5 \\
18 \\
172\end{array}$ & $\begin{array}{c}9 \\
2.5 \\
149 \\
18 \\
178.5\end{array}$ & $\begin{array}{r}44 \\
60 \\
100 \\
100\end{array}$ & $\begin{array}{r}6 \\
10 \\
143 \\
18 \\
177\end{array}$ & $\begin{array}{r}7.5 \\
9.5 \\
144.5 \\
11.5 \\
173.0\end{array}$ & $\begin{array}{l}80 \\
95 \\
99 \\
64\end{array}$ & $\begin{array}{r}9.5 \\
17.0 \\
140.0 \\
26.5 \\
193.0\end{array}$ & $\begin{array}{r}9.5 \\
8.5 \\
144.0 \\
23.5 \\
185.5\end{array}$ & $\begin{array}{r}100 \\
50 \\
97 \\
89\end{array}$ \\
\hline
\end{tabular}

not significant. Thus here, too, the propiles are similar, indicating that the rellability in terms of the odd-even frequencies within each of the three categories is quite adequate.

Another way of indicating rellabllity of the date collected on the 5 infants is by a direct comparison of the results of the three cond1t1ons themselves. These results are found in the two tabulations and in the profiles.

The first of the two tabulations presents the frequencies of each of the vowels under the conditions of consecutive, alternative and fourth

Frequency

\begin{tabular}{|c|c|c|c|}
\hline Vowel & $\begin{array}{l}\text { Conse- } \\
\text { cut1ve }\end{array}$ & $\begin{array}{l}\text { Alter- } \\
\text { native }\end{array}$ & Fourth \\
\hline \multicolumn{4}{|c|}{ Observer I } \\
\hline I & 16 & 12 & 22 \\
\hline$\varepsilon$ & 0 & 20 & 26 \\
\hline $\mathscr{H}$ & 301 & 288 & 284 \\
\hline$\stackrel{\wedge}{\text { Total }}$ & $\begin{array}{r}41 \\
358\end{array}$ & $\begin{array}{r}28 \\
348\end{array}$ & $\begin{array}{r}55 \\
387\end{array}$ \\
\hline \multicolumn{4}{|c|}{ Observer Ch } \\
\hline I & 10 & 15 & 16 \\
\hline$\varepsilon$ & 8 & 19 & 25 \\
\hline$x$ & 294 & 287 & 284 \\
\hline$\wedge$ & 31 & 31 & 45 \\
\hline Total & 343 & 352 & 370 \\
\hline
\end{tabular}


IFWIN: RELIABILITY IN OBSERVING SOUNDS

SAMPLE RELIABILITY OF PER CENT OF FREQUENCY OF SOUNOS OF FIVE NEWBORNS FOR ODD AND EVEN BREATHS UNDER THREE CONDITIONS (BASED ON THE AVERAGED RESULTS OF $I$ (CH.)

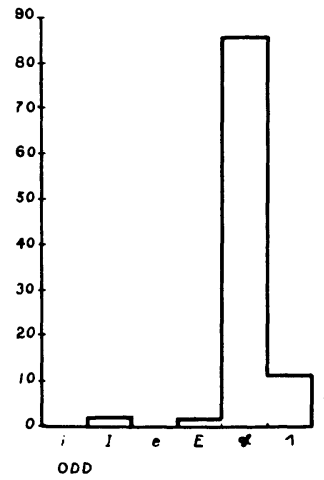

CONSECUTIVE

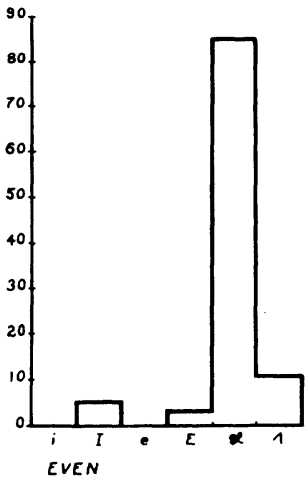

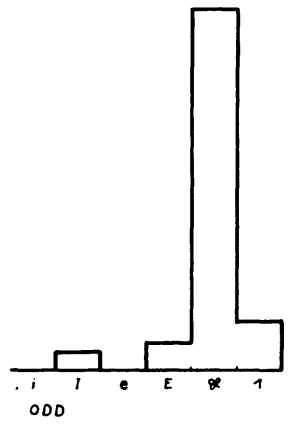

ALTERNATIVE

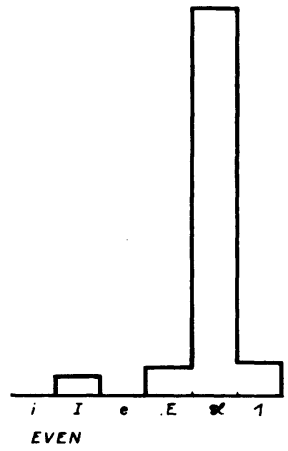

FIGURE 5

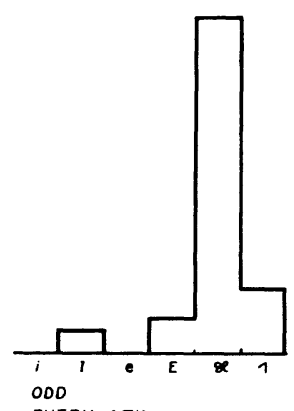

EVEAY 4-TH

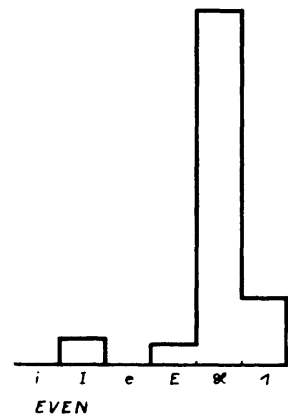

transcriptions for the two observers and also for the average of their results. When these values are turned into percentages and these percentages are compared in terms of consecutive vs. alternate, consecutive vs. lourth, and altermative vs. fourth, the results may be seen in

\begin{tabular}{cccc} 
Vowel & \multicolumn{3}{c}{ Frequency } \\
& $\begin{array}{c}\text { Conse- Alter- } \\
\text { cut1ve native }\end{array}$ & Fourth \\
\multicolumn{4}{c}{ Average } \\
I & 13 & 13.5 & 19 \\
$\varepsilon$ & 4 & 19.5 & 25.5 \\
$\mathscr{H}$ & 297.5 & 287.5 & 284 \\
$\wedge$ & 36 & 29.5 & 50 \\
Total & 350.5 & 350 & 378.5
\end{tabular}


the next tabulation. The indices are quite satisfactory on the sound $\mathscr{H}$, fairly satisfactory for the sounds $\underline{\Delta}$, and $\underline{I}$, and in two comparisons not satisfactory for the sound $\varepsilon$.

Agreement, Per Cent

Vowel Consecutive consecutive

vs.

Alternative Every 4th

Alternative

Observer I

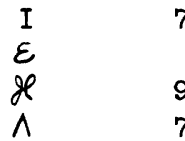

77

60

77

87

81

vs.

Every 4th

98

70

85

89

Observer $\mathrm{Ch}$

$\begin{array}{ll}I & 67 \\ \varepsilon & 43 \\ \mathscr{H} & 95 \\ 1 & 97\end{array}$

67

67

34

89

Average 75

57.

43

97

I $\quad 95$

74

16

88

म 97

$\begin{array}{ll}82 & 78\end{array}$

100

79

94

72

$\wedge \quad 82$

78

84

91

63
DISTRIBUTION OF VOWEL SOUNDS OF FIVE INFANTS
UNDER THREE CONDITIONS
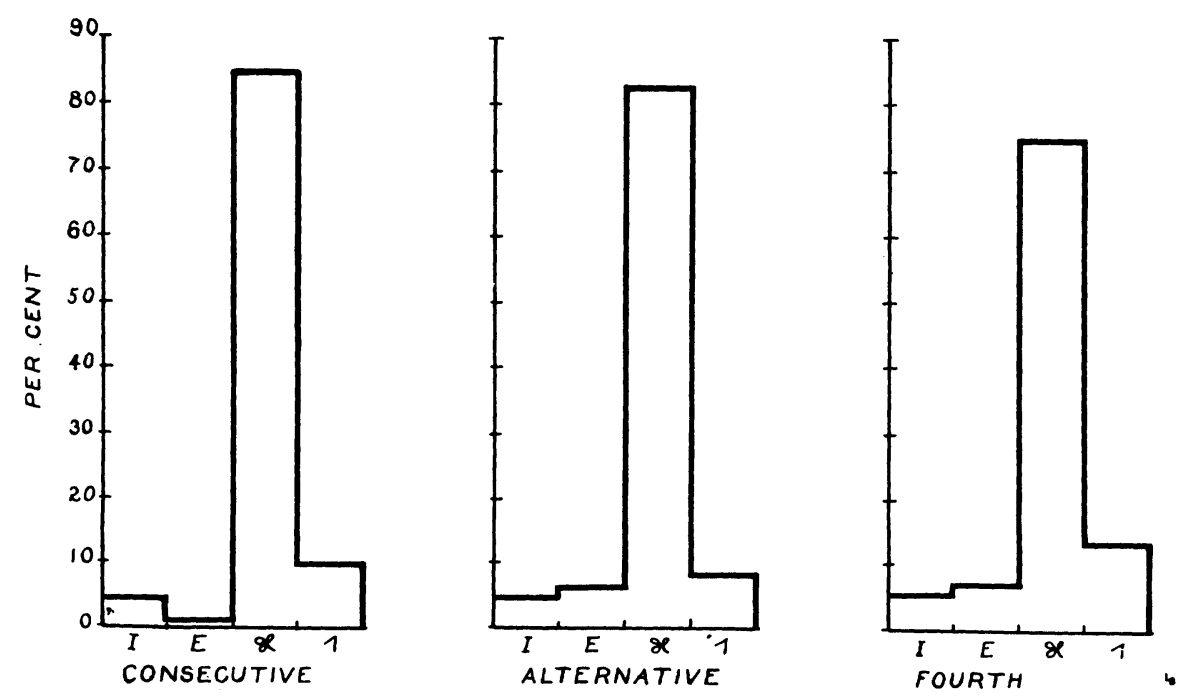

FIGURE 6 
When the values in the third part of the frequency tabulation above are turned into per cents and graphed as profiles, the similarity of the patterns becomes evident. The rank order of the sound erequency for $\&$ and for $\Lambda$ is first and second under all three conditions. For the alternative and the fourth transcriptions $\varepsilon$ ranks third, and I fourth. However, in the case of the consecutive transcription $\underline{\varepsilon}$ and $I$ are reversed.

\section{Comparison of the Results of Three Experiments}

In the discussion of observer rellability the similarity between the profile patterns of pairs of observers in Figure 1 was pointed out. F1gure $I$ also may be used to graphically 1llustrate data reliabillty. By reading the elgure vertically it will be seen that the successive profiles of the three samples transcribed by observer I are very sim1lar. The same is true of the two samples collected by observer $\mathrm{Ch}$.

In the distribution of the use of the seven vowels shown in the Irwin-Curry data, the sound $\mathscr{R}$ is strikingly dominant. The $\underline{\varepsilon}$ sound ranks second and a few back vowels are present. Likewise in the dispersion of sounds 1llustrated in the profiles of experiment 1 , the element \& 1 s clearly dominant among the flve sounds transcribed, and $\Lambda$ ranks second. One back vowel is rarely present. Forty infants were used in both of these samples. In the data of experiment 2 on 5 infants, the sound $\&$ likewise stands out prominently, the $\Lambda$ sound ranks second, but no back vowels were heard.

Thus Flgure I may be taken as a demonstration not only of observer rellabll1ty, but also of data reliability.

\section{SUMMARY}

In order to determine the degree of observer and data rellability which can be achieved on speech sound data, two experiments were conducted on the speech sounds of infants under 10 days of age. The first exper1ment included a sample of vowels occurring on 30 respirations of each of 40 infants; the second, a sample of 180 respirations on each of 5 infants. Transcriptions were made in the International Phonetic Alphabet by two observers working simultaneously and independently. These data together with those of a previous study constitute the materlals which have been analyzed. Methods of calculating the rellability of this type of data are described. The following results were obtained:

1. Whining and crying may be rellably discriminated. The agreement 1ndex for the two observers averages 97 per cent.

2. Agreement of observers on crying sounds of the group of 40 infants 1s 93 per cent on a frequency criterion; for a breath criterion, 1t is 91 per cent. The range in both cases is from 74 to 100 per cent.

3. On the erequency criterion there was observer agreement above 85 per cent in 36 of the 40 infants.

4. On the breath criterion there was agreement above 85 per cent on 33 of the 40 cases.

5. Profiles of vowel dispersion as transcribed by three pairs of observers are strikingly similar.

6. It is evident that training in transcribing infant sounds on about 18 subjects will yleld observer rellabll1ty above 90 per cent.

7. There are reasons for belleving that when the methods of fre- 
quency and breath rellability are both used, a more complete result is obtained than when either is used singly.

8. When transcriptions of samples on consecut1ve, alternative, and fourth sounds are compared as between observers, the frequency rellability is 96 per cent and breath rellability is 95 per cent.

9. For the separate sounds vocalized by the group of 40 bables, the per cent of observer agreement varied from 60 on the sound $I$ to 99 on the sound $\mathcal{H}$. The average for the Ifve vowels uttered by this group is 85 per cent.

10. For the separate vowel sounds of the group of 5 subjects, the per cent of observer agreement varled from 82 on the sound $I$ to 99 on the sound fl. The average for four sounds uttered by this group is 89 per cent.

11. When the reliability of the data is analyzed in terms of consecutive, altermative and fourth samplings and presented graphically in profiles of vowel dispersion, a high degree of similarity is evident.

12. A comparison of odd-even 1tems of the vowel sounds of the group of 40 cases shows agreement ranging from 68 to 99 per cent with an average of 87 per cent.

13. A profile comparison of the odd-even 1tems within each of the conditions of consecutive, altermative, and fourth transcriptions shows close similarity.

14. A comparison of the distributions of sounds between consecutive and alternative transcriptions, between consecutive and fourth, and between alternative and fourth transcriptions yields satisfactory reliablilty on 9 of 12 indices.

15. When the findings of the two experiments of the present study are compared by means of profiles with the results of a previous exper1ment it is seen that the data show a high degree of simflarity.

16. A sample of the sounds of 30 breaths of 40 infants seems to yleld more individual sounds than the sample of 180 breaths of 5 subjects.

It is concluded from these findings that quite adequate observer and data reliability can be attained on the speech sounds of newborm infants.

\section{REFHEREANCES}

(1) Irwin, Orv1s C.: Research on speech sounds for the first six months of 111e. Psychol. Bull., 1941, 38, 277-285.

(2) Irwin, Orvis C., and Curry, Theyer: Vowel elements in the crying vocalization of infants under ten days of age. Child Develop., 1941, 12, 99-109.

(3) Irwin, Orv1s C., and Krehbiel, Thelma E.: Speech sounds of infants: The fourth, f1fth, and sixth months. Unpublishod study.

(4) Irwin, orvis C.: The profile as a visual device for indicating central tendencies in speech date. Child Develop., 1941, 12, 111-120.

(5) McCarthy, Dorothea: The vocalization of infants. Psychol. Bull., 1929, 26, 625-651. 